\title{
International Experience and Reference of PPP Model in Inclusive Preschool Education
}

\author{
Meng Zhang ${ }^{1, \text { a }}$, Yang Liu ${ }^{2, \mathrm{~b}}$, Jing Cheng ${ }^{3, \mathrm{c},{ }^{*}}$ \\ ${ }^{1}$ Shaanxi Xueqian Normal University, Xi'an 710100; X'an Jiaotong University, Xi'an, 710061, China \\ ${ }^{2}$ Kunming University; Kunming, Yunnan 650091, China \\ ${ }^{3}$ Yunnan Agriculture University; Kunming, Yunnan, 650021, China \\ a396326675@qq.com, b2275100825@qq.com, ${ }^{\text {c, }}$ 775850497@qq.com
}

\begin{abstract}
In order to standardize the marketization and privatization reform of inclusive preschool education and apply PPP model of inclusive preschool education scientifically and effectively, this paper firstly introduces the main forms and implementation status of PPP model of basic education in foreign countries. And then analyses the achievements and existence of PPP model of basic education in foreign countries. Finally, the author puts forward the experience worth learning and using for reference in the exploration of PPP for inclusive preschool education in China.
\end{abstract}

Keywords: Inclusive Kindergarten; PPP School-running Model; International Experience.

\section{Introduction}

Preschool education is the starting point of education, the critical period for children to learn social norms, which is of great significance to the socialization of human life. Therefore, ensuring the fairness of preschool education is an important aspect of reflecting social fairness. Firstly, inclusive kindergartens provide the same right to education for children of different income, gender, occupation, educational level and ethnic families from the perspective of equal educational opportunities, which fully embodies Rawls' principle of equality and freedom; secondly, the low fee standard of inclusive kindergartens helps to reduce it. The economic pressure of children's families reflects the principle of compensatory education. It is a common understanding of governments to build a perfect national basic education system. Especially developed countries in Europe and the United States have basically established a "public welfare" and "inclusive" basic education system covering all stages of children, primary schools and secondary schools. This article provides useful reference for our country's inclusive preschool education by analyzing the experience of the typical mode of PPP in the field of basic education abroad.

\section{International Practice of PPP in Basic Education}

Since the 1970s, with the economic development of western countries generally falling into "stagflation", governments have implemented economic reforms marked by marketization and privatization. In the field of basic education with typical "public service" characteristics, problems such as inadequate financial investment, declining quality of education services and inefficient administration are becoming increasingly prominent. Western countries led by Europe and the United States are taking the lead in trying to reform the marketization and privatization of preschool education, namely "public-private partnership model" (PPP for short). Model). In the long-term practice and exploration, various countries have gradually formed a variety of organizational modes based on different goals of public service improvement in preschool education.

\subsection{Public-Private Cooperation in School Infrastructure Construction}

Public-private partnership in school infrastructure construction is one of the earliest PPP School-running Models in the developed West. Generally, the government franchises private institutions to construct part or all of the basic facilities of the school. After completion, the private institutions will operate and manage the facilities during the contract period, and the government departments will 
pay the corresponding fees to the private institutions. After the expiration of the contract, the private institutions will deliver deliver operating rights to government departments free of charge. Typical examples of this model include the Private Financing Initiative (PFI) launched in 1992 in Britain and the New Campus Project (NSP) launched in 2002 in South Wales, Australia. The PPP model of school infrastructure construction in countries such as Britain and Australia has the following common characteristics: Firstly, private institutions are only responsible for investing in facilities construction funds and non-core services to inclusive kindergartens; Secondly, government departments strictly control core services such as education and teaching; Thirdly, long contract period between government and private institutions (about 30 years). The contract specifies the rights and obligations of both parties in detail; Fourthly, infrastructure construction and franchising appear in a bundled way, and private institutions are responsible for the design, construction and maintenance of Inclusive Early Childhood Education infrastructure; Fifthly, government departments pay after private institutions meet the contract requirements.

\subsection{School "Adoption"}

"Adoption" refers to the PPP model in which private institutions subsidize government-run schools by means of funds, material objects and labor services, so as to improve school running conditions. At the same time, the government gives preferential policies such as tax reduction to private institutions. The Academic Adoption Scheme (AAS), which was formally approved by the Philippines in 2003 and implemented nationwide, is a typical representative of this PPP model. AAS sets 20 provinces with relatively backward basic education as priority adoption sequence. AAS stipulates that the "adoption" period should be at least two years. There are various ways of "adoption", such as renewing equipment, purchasing textbooks and providing funds for schools. After "adoption", the supervisory and Coordinating Committee evaluates "adoption" in accordance with the criteria and gives tax relief policies to private institutions that have passed the evaluation. Within three years of AAS implementation, 2,000 inclusive kindergartens were "adopted" by 300 private institutions and received more than $\$ 50$ million of personal support. "Adoption" has charitable nature, but it is essentially different from charitable donations in the general sense. The ultimate goal of adoption is to establish a long-term and sustainable partnership between inclusive kindergartens and private institutions.

\subsection{Public Schools Running by Private}

This model is to deliver all or part of the management content of public schools to social institutions, which still retains the public nature and appropriation are managed by the government. However, unlike public schools, private institutions operate and are responsible for specific tasks such as school education, use of fund and personnel employment. Under this model, private institutions must be supervised and inspected by government departments to ensure that their performance meets the requirements of the government. For example, this kind of schools in the United States allow social institutions to establish their own boards of directors, have independent personnel management rights, and make financial budgets according to their own circumstances by signing franchise contract. They have higher autonomy. At the same time, a very strict assessment system has been set up, requiring social institutions to accept the performance appraisal of the education authorities at any time.

\subsection{Supply Model by Agreement}

The supply model by agreement refers to the place, infrastructure and educational content provided by social institutions to carry out education and teaching. Under this model, the transfer agreement of educational services has developed from the auxiliary field to the core field. In 1998, Britain formulated the "Transfer of Local Educational Functions Plan", which transfers the teaching improvement, curriculum design, monitoring and evaluation and other educational auxiliary services which is originally in charge of the government education department to the social institutions. 


\subsection{Directional Voucher Model}

Directional vouchers are the certificate of funds issued by the government to parents of school-age students for their children's education. The students with directional vouchers can study in government-designated schools, and tuition fees equal to the face value of vouchers can be deducted. As early as 1989, Wisconsin adopted the directional voucher model, named "Milwaukee Parent Choice Program" (MPCP), in order to help poor families obtain equal educational resources. Relevant data show that $72 \%$ of African-American families, $21 \%$ of Hispanic families, $78 \%$ of families have an annual total income of less than 29,000 yuan and $75 \%$ are single-parent families have acquired the educational vouchers. American society generally believes that MPCP has achieved success in helping children of vulnerable groups. However, some critics still believe that the total amount of the plan is limited, and it still can not fundamentally solve the problem of insufficient resources and uneven distribution of early childhood education.

\section{Achievements and Problems of PPP Model in Basic Education in other Countries}

\subsection{Achievements of PPP School-running Model}

Firstly, the PPP model of running schools has changed the public's understanding of the supply of basic education. Traditionally, the basic education should belong to the public goods. The government, as a builder, operator and manager, has three identities, which leads to a series of problems, such as the decline of education quality, education corruption and the rigidity of management system. The PPP model of running schools introduces the concept of contract performance in market regulation mechanism into basic education, which can reduce government financial pressure. It also can solve the contradiction between government centralization and decentralization. This school-running concept has changed the understanding of basic education supply in various countries and provided new development ideas for inclusive preschool education in China.

Secondly, the PPP school-running model not only improves the supply capacity of basic education, but also improves the level of equity and efficiency of education. PPP model is an important supplement to traditional public basic education, which attracts more private capital and solves the problem of insufficient supply of basic education. In the contract, the clear requirements for the qualification and educational objectives of private institutions ensure the teaching quality, and also form a healthy competition for public schools.

Thirdly, PPP school-running model promotes the development of school-running and management system of preschool education. Under the PPP model, a new type of risk and responsibility relationship has been formed between the government and private institutions, which is conducive to the government focusing on educational science decision-making, education quality supervision and other matters. Moreover, the PPP school-running model enriches the organization and management mode of basic education, forms a benign competition with the government education supply and private education supply. It promotes the improvement of the quality of early childhood education. PPP model gives private institutions more autonomy, so educational arrangements are more flexible, which can help to change the rigid employment and rigid working procedures in public basic education and avoid corruption in the process of educational management. So that it can improve the efficiency of resource utilization.

Finally, it expands the sources of funds for basic education. PPP school-running model enables basic education to obtain more funds from society. It effectively alleviates the contradiction between the shortage of funds and public demand for basic education. In addition, the fund in PPP schoolrunning model is managed by private institutions, so it is more flexible to use. A world bank survey shows that public schools run by private institutions (including preschool education) under the PPP model can achieve better educational outcomes with lower investment. 


\subsection{Problems in PPP School-running Model}

There are still doubts about the effect of PPP. The authority of public basic education is still incomparable with other school-running models. The authority and public welfare of PPP schoolrunning model integrated with privatization are bound to be weakened. In addition, the profit-making nature of private institutions inevitably drives them to obtain the highest benefits with the lowest investment, which may result in the reduction of the quality of inclusive preschool education. Moreover, the PPP model of inclusive kindergartens may lead to new educational inequity by increasing parents' choices, but the children in families with more choice capital will inevitably study in the high-quality schools. At the same time, there are some risks and challenges in PPP model. Although some countries have achieved tremendous success in adopting PPP school- running model, some scholars have proposed that the current survey of the effect of PPP model almost all originated from the United Kingdom. It is doubtful whether this regional limited evaluation result can represent all countries. Some scholars also find that the overall quality of education in Chile has not been significantly improved after the application of the PPP model. Therefore, they believe that the impact of the PPP model on the quality of education needs to be studied more carefully.

\section{International Experience and its Enlightenment to China}

Since the reform and opening up 40 years ago, preschool education in China has made great strides in terms of quality and quantity. However, the problems of "difficulty" and "expensive" still exist widely. Therefore, many local governments in China have introduced market competition mechanism into preschool education, such as franchising, civil construction and public rent, public-owned private enterprises, comprehensive awards and supplements. However, there are many problems in the process of PPP reform in China, which poses new challenges to the relationship between government, kindergarten and market in preschool education. Learning from international experience is helpful to the scientific planning and rational exploration of PPP model of inclusive preschool education in China.

Firstly, there are great differences between China and other countries in terms of national conditions, cultural environment and educational characteristics. Therefore, we can't copy the mature model of foreign countries, but should construct the PPP model of inclusive preschool education according to the actual situation of our country. The government should collect and analyze the information needed for preschool education, evaluate the supply of potential private institutions, and then compare the demand and supply to find out the specific mode of PPP for inclusive preschool education in China. Pilot projects should be carried out on a small scale and steadily promoted to a large scale after accumulating certain experience.

Secondly, we should recognize the role of private institutions in early childhood education at the legal level and encourage the development of PPP school-running model. Under the legal framework, government education departments can form protective mechanism and compensation measures for PPP model, clearly define the position and basic rights of private institutions in educational cooperation and minimize the political and legal risks of inclusive public-private cooperation in preschool education.

Thirdly, we should formulate a scientific and reasonable cooperation framework for PPP schoolrunning model. At present, most countries tend to adopt strict censorship system for private institutions in PPP projects. There are some unreasonable clauses which limit the enthusiasm of private institutions to invest in inclusive preschool education. Therefore, we can formulate objective and open qualifications according to China's specific national conditions, and encourage private institutions and government education departments to conclude PPP school-running contracts. Qualification criteria should be objective and easy to assess, reflecting the spirit of openness and fairness. When examining the qualifications of private institutions, audit deadline should be established, and the detailed process of examining should be published through the network to prevent corruption. The government should set up reasonable appeal and review procedures to provide a list of reasons for failed private institutions. 
Fourthly, investment and technology from international educational organizations should be introduced. Our country's inclusive preschool education PPP model is still in its infancy. If we want to achieve rapid development in a short time and ensure the quality of development, we must learn from developed countries. From foreign experience, PPP model of basic education has a long period of operation. Obtaining international investment will help the country to enhance the brand image of cooperative projects, reduce the uncertainty in the process of project implementation, and effectively avoid potential risks. For example, 57\% of the World Bank's investment in education projects in 2017 involves the PPP school-running model, which not only provides funding for inclusive preschool education PPP school-running projects, but also provides legal and regulatory advisory services and operational decision-making and evaluation system of the cooperation model. The introduction of investment and technology from international educational organizations into China's inclusive preschool education PPP project in the initial demonstration stage can not only provide a demonstration role for domestic private organizations, but also obtain relatively stable long-term funds.

Finally, in the process of exploring the PPP model in inclusive preschool education, it will inevitably encounter misunderstandings and conflicts from the public. Therefore, before the start of the project, we should do a good job in the promotion and publicity work, so that the public can understand the benefits. The public will understand that the educational administrative department is still responsible for the supply of preschool education. The PPP model is only the reform of educational supply.

\section{Acknowledgements}

Foundation: General Projects of Shaanxi Science and Technology Program (Soft Science) in 2017 (2017KRM190),Key Research Projects of Shaanxi Education Department in 2017 (17JZ021), Key projects of scientific research foundation of Shaanxi Pre-school Education Demonstration College in 2016 (2016ZDKJ015), Joint Special Project of Basic Research in Yunnan Local Undergraduate Colleges and Universities in 2017 (2017FH001-114).

\section{References}

[1]. Cameiro P. M., Ginja R. Long Term Impacts of Compensatory Preschool on Health and Behavior: Evidence from Head Start[J]. Social Science Electronic Publishing, 2014, 6(4): 135-173.

[2]. Gürtekin, Pembe, Baskan, et al. The History of Turkish and Cyprus Turkish Education Teacher Training Policies Teacher Training in National Education Councils and Development Plans[J]. Procedia-Socialand Behavioral Sciences, 2013(89): 835-840.

[3]. Harry A. P., Felipe B. O. and Juliana G. The Role and Impact of Public-Private-Partnerships in Education[M]. Washington D.C.: World Bank Publications, 2009.

[4]. Larocque N. Public-Private-Partnerships in Basic Education: An International Review[J]. CFBT Education Trust, 2009, 24(09): 873-894.

[5]. T. Husèn, A. Tuijnman, W. D. Halls. Schooling Modern European Society: A Report of the Academia European[M]. Oxford: Pergamon Press, 1992.

[6]. Bao Haiqin, Xie Xiaole. Research on Preschool Education Supply from the Perspective of QuasiPublic Goods [J]. Educational Review, 2017, (09): 3-7.

[7]. Feng Xiaoxia. Vigorously developing inclusive kindergartens is the fundamental solution to the difficulty of entering kindergartens. [J]. Preschool Education Research, 2010, (05): 4-6.

[8]. Li Feilong. Practice and Enlightenment of PPP mode of basic education abroad [J]. Foreign Education Research, 2010:37 (07): 1-5. 
[9]. Liu Wei. The theoretical interpretation of PPP model and its practical examples [J]. Reform, 2015, (01): 78-89.

[10]. Pang Lijuan, Han Xiaoyu. China's Preschool Education Legislation: Thinking and Process [J]. Journal of Beijing Normal University (Social Science Edition), 2010, (05): 14-20.

[11]. Tang Xianglai, Ni Lin. International Public-Private Partnership for Basic Education (PPP) Model: Debate and Enlightenment [J]. Foreign Education Research, 2013, 40 (04): 88-95.

[12]. Zhuangxiaoman, Cheng Lisheng. Significance, predicament and Countermeasures of developing inclusive private kindergartens [J]. Pre-school education research, 2012, (11): 45-49. 